University of Nebraska - Lincoln

DigitalCommons@University of Nebraska - Lincoln

Transactions of the Nebraska Academy of

Sciences and Affiliated Societies

Nebraska Academy of Sciences

Summer 7-30-2020

\title{
Snowy Plover Activity in the Central Platte River Valley in May 2019
}

Bethany L. Ostrom

Platte River Whooping Crane Maintenance Trust, bostrom@cranetrust.org

Andrew J. Caven

Platte River Whooping Crane Maintenance Trust, acaven@cranetrust.org

Jenna M. Malzahn

Platte River Whooping Crane Maintenance Trust, jmalzahn@cranetrust.org

Alyx Vogel

Platte River Whooping Crane Maintenance Trust, avogel@cranetrust.org

Follow this and additional works at: https://digitalcommons.unl.edu/tnas

Part of the Behavior and Ethology Commons, and the Ornithology Commons

Ostrom, Bethany L.; Caven, Andrew J.; Malzahn, Jenna M.; and Vogel, Alyx, "Snowy Plover Activity in the Central Platte River Valley in May 2019" (2020). Transactions of the Nebraska Academy of Sciences and Affiliated Societies. 525.

https://digitalcommons.unl.edu/tnas/525

This Article is brought to you for free and open access by the Nebraska Academy of Sciences at DigitalCommons@University of Nebraska - Lincoln. It has been accepted for inclusion in Transactions of the Nebraska Academy of Sciences and Affiliated Societies by an authorized administrator of DigitalCommons@University of Nebraska - Lincoln. 


\title{
Snowy Plover Activity in the Central Platte River Valley in May 2019
}

\author{
Bethany L. Ostrom, Andrew J. Caven, Jenna M. Malzahn, and Alyx Vogel \\ Platte River Whooping Crane Maintenance Trust, Wood River, NE 68883, USA \\ *Corresponding author: acaven@cranetrust.org; (605)-252-8007
}

\begin{abstract}
During five of eight site visits between 14 and 27 May 2019 we detected up to four Snowy Plovers (Charadrius nivosus nivosus) in the Central Platte River Valley (CPRV) near Mormon Island, Hall County, Nebraska, and recorded their behavior using an instantaneous scan sampling approach. We recorded loafing (47\%), foraging (43\%), mating (4\%), flying (4\%), and external threat (1\%) related behavior. Most notably, we documented a copulation event on 23 May. During the 10-day span from 14 to 23 May when Snowy Plovers were detected, river stage and discharge were near median levels, but from 23 to 27 May river discharge more than doubled and gage height increased by over $20 \%$. This resulted in sandbar habitat becoming submerged and the Snowy Plovers vacating the site. This observation illustrates how wide variation in late spring flows can preclude potential breeding by ground nesting waterbirds in the CPRV given the current limited availability of unvegetated sandbars significantly exceeding flood stage. This represents a notable late-spring stay length in the CPRV with behavior suggestive of the potential for local breeding.
\end{abstract}

Keywords: Snowy Plover, Waterbird, Braided River, Central Platte River Valley, Sandbar, Distribution, Natural History, Breeding, Copulation

doi: $10.32873 /$ unl.dc.tnas.40.4

\section{Introduction}

Snowy plovers (Charadrius nivosus nivosus) typically breed and nest throughout the Great Plains in Colorado, Kansas, and Oklahoma on sparsely vegetated sandy shores of lakes, ponds, reservoirs, riverine sandbars, and mudflats (Thompson and Ely 1989, Page et al. 2009, Thomas et al. 2012, Johnsgard 2018). In Nebraska, the species, while uncommon, is most frequently sighted during short visits in the spring, is less common in the summer, and rarely stays to nest (Silcock and Jorgensen 2018). However, Peyton and Wilson (2005) recorded 9 Snowy Plover nests, 19 broods, and 35 chicks during the 2004 and 2005 breeding seasons at Lake McConaughy, with relatively high nest $(67 \%)$ and fledgling $(91 \%)$ success rates. When breeding does occur in Nebraska it is typically around Lake McConaughy during dry periods, along the Missouri River, or very rarely within the Central Platte River Valley (CPRV) (Peyton and Wilson 2005, Baasch 2010, Johnsgard and Brown 2013, Johnsgard 2018, Silcock and Jorgensen 2018). The Platte River is a braided river system that experiences seasonal flooding, which creates suitable breeding habitat on sandbars for many ground nesting waterbird species including Interior Least Terns (Sterna antillarum athalassos) and Piping Plovers (Charadrius melodus), particularly in the Lower Platte River Valley (Kirsch 1996, Alexander et al. 2018). Within the CPRV, evidence of successful Snowy Plover nesting has only been documented at the Dinan Memorial Tract in Buffalo County in 2007 ( 1 of 2 nests successful) and 2009 (1of 1 nests successful) (Baasch 2010, Silcock and Jorgensen 2018). In this report, we summarize
Snowy Plover behavior from mid-late May in the eastern portion of the CPRV during a spring stay of notable duration that included mating behavior. We also describe the habitat in which they were observed.

\section{Methods}

On 14 May 2019 at 1000 hrs. we detected two Snowy Plovers while conducting regular avian migration monitoring of conservation lands owned and managed by the Platte River Whooping Crane Maintenance Trust (henceforth "Crane Trust") near Mormon Island, approximately $17 \mathrm{~km}$ (10.6 mi.) SW of Grand Island, Nebraska, USA (40.78856 ${ }^{\circ} \mathrm{N},-98.44016^{\circ} \mathrm{W}, 581 \mathrm{~m}$ (1906 ft.) elevation). Following this detection we recorded notes regarding the habitat conditions including estimated sandbar area and height, unobstructed channel width (perpendicular width bank to bank subtracting stabilized vegetated islands; see Baasch et al. 2019), and bank vegetation characteristics. After the initial sighting on 14 May, we revisited the site between 0800 and $1300 \mathrm{hrs}$. seven more times from 16 to 27 May 2019 and conducted instantaneous scan sampling of behavior at 1-minute intervals for a minimum of 30 minutes (Altman 1974). We categorized the behavior of each individual into the following groups: "nesting behavior," included activities such as building or occupying a nest; "mating display," included courtship displays and copulation; "loafing," included preening and resting; "foraging," included scanning and occasionally pecking at the ground; "territorial display," included dominance displays through fighting 


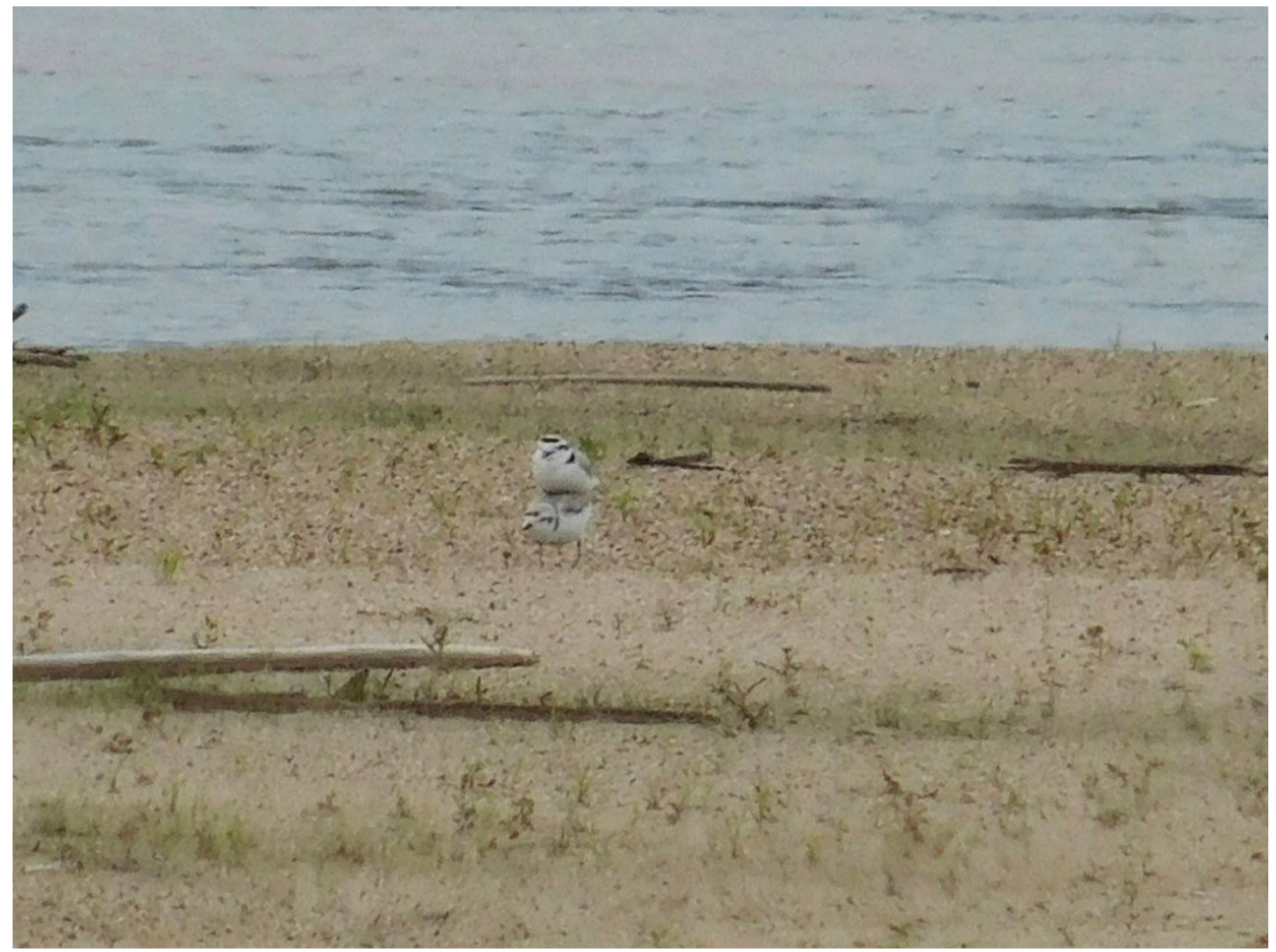

Figure 1. Image of a Snowy Plover (Charadrius nivosus nivosus) copulation on 23 May 2019, located on a sandbar in the main (south) channel of the Platte River near Mormon Island, 17 km SW of Grand Island, Nebraska, USA (Photo Credit - Jenna Malzahn).

and charging; "flight," including any distance of airborne travel; and "external threat response," included retreating to safety, alarm calls, and broken wing displays, etc. (Page et al. 2009). We monitored the area until we did not detect Snowy Plovers for two consecutive visits. We consulted data from the USGS National Water Information System for the Platte River station near Grand Island, Nebraska, which is $17 \mathrm{~km} \mathrm{NW}$ and downstream of our study site (USGS 06770500; $40.874444^{\circ} \mathrm{N},-98.281667^{\circ} \mathrm{W}, 560 \mathrm{~m}$ (1838 ft.) elevation) during the birds' dates of occurrence to determine if the river's flow or stage height were associated with the birds' departure.

\section{Results}

We detected between two and four adult Snowy Plovers on five of our eight site visits and scan sampled for a total of two hours and three minutes. None of the Snowy
Plovers were banded or had otherwise distinguishable characteristics. We detected two Snowy Plovers on the $14^{\text {th }}$, three on the $16^{\text {th }}$, four on the $17^{\text {th }}$, two on the $20^{\text {th }}$ and $23^{\text {rd }}$, and zero on the $22^{\text {nd }}, 25^{\text {th }}$, and $27^{\text {th }}$ of May. Through the entirety of the sampling we witnessed five behaviors: loafing $(47 \%)$, foraging $(43 \%)$, mating displays (4\%), flying (4\%), and external threat displays (1\%). On 23 May 2019 we observed a mating ritual and copulation similar to the one described in Boyd (1972). Seven minutes before copulation one Snowy Plover, presumably male, nest scraped, as the other, presumably female, sat in a recently made scrape observing. Next, the male started a "horizontal dance" as described in Boyd (1972) then persisted to create scrapes as the female continued to occupy various scrapes. Finally, the female stood up from a scrape and the male mounted the female's back (Figure 1). Copulation lasted about three minutes and 


\section{FUSGS}

USGS 06770500 Platte River near Grand Island, Nebr.

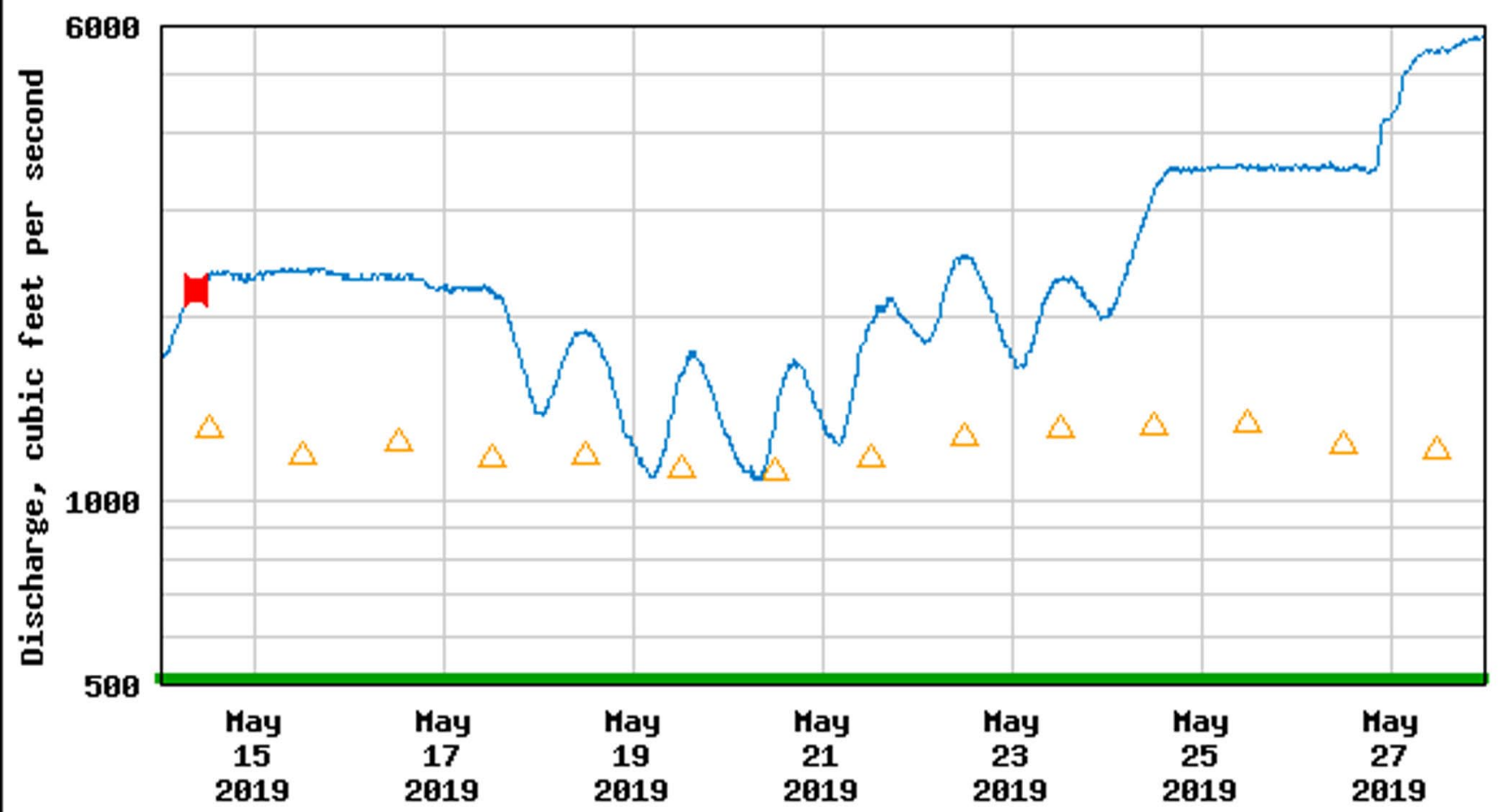

\section{$\triangle$ Median daily statistic (78 years) Period of approved data - Discharge Measured discharge}

Figure 2. Observed Platte River discharge in cubic feet per second at United States Geological Survey site no. 06770500 near Grand Island, Nebraska, from 15 to 27 May 2019, presented along with median discharge values (Figure Credit - USGS 2020).

was terminated by the female falling backwards and the male dismounting.

The Snowy Plovers were detected in the south (main) channel of the Platte River on a sandbar in the middle of the channel that we visually estimated to span $\sim 35 \mathrm{~m}$ (115 $\mathrm{ft}$.) in length (parallel to river banks), $\sim 25 \mathrm{~m}(82 \mathrm{ft}$.) in width (perpendicular to river banks), and about $20-30 \mathrm{~cm}$ (8-12 in.) in height above the water at the sandbar's highest elevation as of 14 May 2019 (discharge $=63.4 \mathrm{~m}^{3} / \mathrm{s}$ $\left(2,240 \mathrm{ft}^{3} / \mathrm{s}\right)$, stage height $=1.27 \mathrm{~m}(4.18 \mathrm{ft}$.); USGS 2020). We also visually estimated that vegetative cover on the sandbar was about $10-15 \%$ and composed of short stature ( $<10 \mathrm{~cm}$ (4 in.) height) early successional vegetation. We estimated the total unobstructed channel width at the site was $260 \mathrm{~m}$ (853 ft.) using Google Earth Pro Version 7.3 and aerial imagery from March 2019 (Google 2018).
Habitat on the north bank of the channel was predominantly lowland tallgrass prairie dominated by warm season grasses such as Big Bluestem (Andropogon gerardii) and forbs such as Maximilian Sunflower (Helianthus maximiliani). Habitat on the south bank of the channel was predominantly riparian woodland dominated by Plains Cottonwood (Populus deltoides spp. monilifera) and an understory of Eastern Redcedar (Juniperus virginiana) and Coyote Willow (Salix exigua).

During the Snowy Plovers' visit, the Platte River near Grand Island, NE had a flow rate between $30.6 \mathrm{~m}^{3} / \mathrm{s}(1,080$ $\left.\mathrm{ft}^{3} / \mathrm{s}\right)$ and $74.8 \mathrm{~m}^{3} / \mathrm{s}\left(2,640 \mathrm{ft}^{3} / \mathrm{s}\right)$ and a gage height between $1.11 \mathrm{~m}(3.65 \mathrm{ft}$.) and $1.32 \mathrm{~m}(4.32 \mathrm{ft}$.), which closely followed the median daily values for the past 11 years (Figures 2, 3; USGS 2020). However, discharge and gage height began to increase on 24 May to $99.7 \mathrm{~m}^{3} / \mathrm{s}(3,520$ 


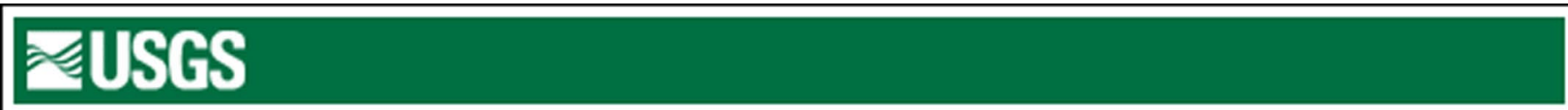

USGS 06770500 Platte River near Grand Island, Nebr.

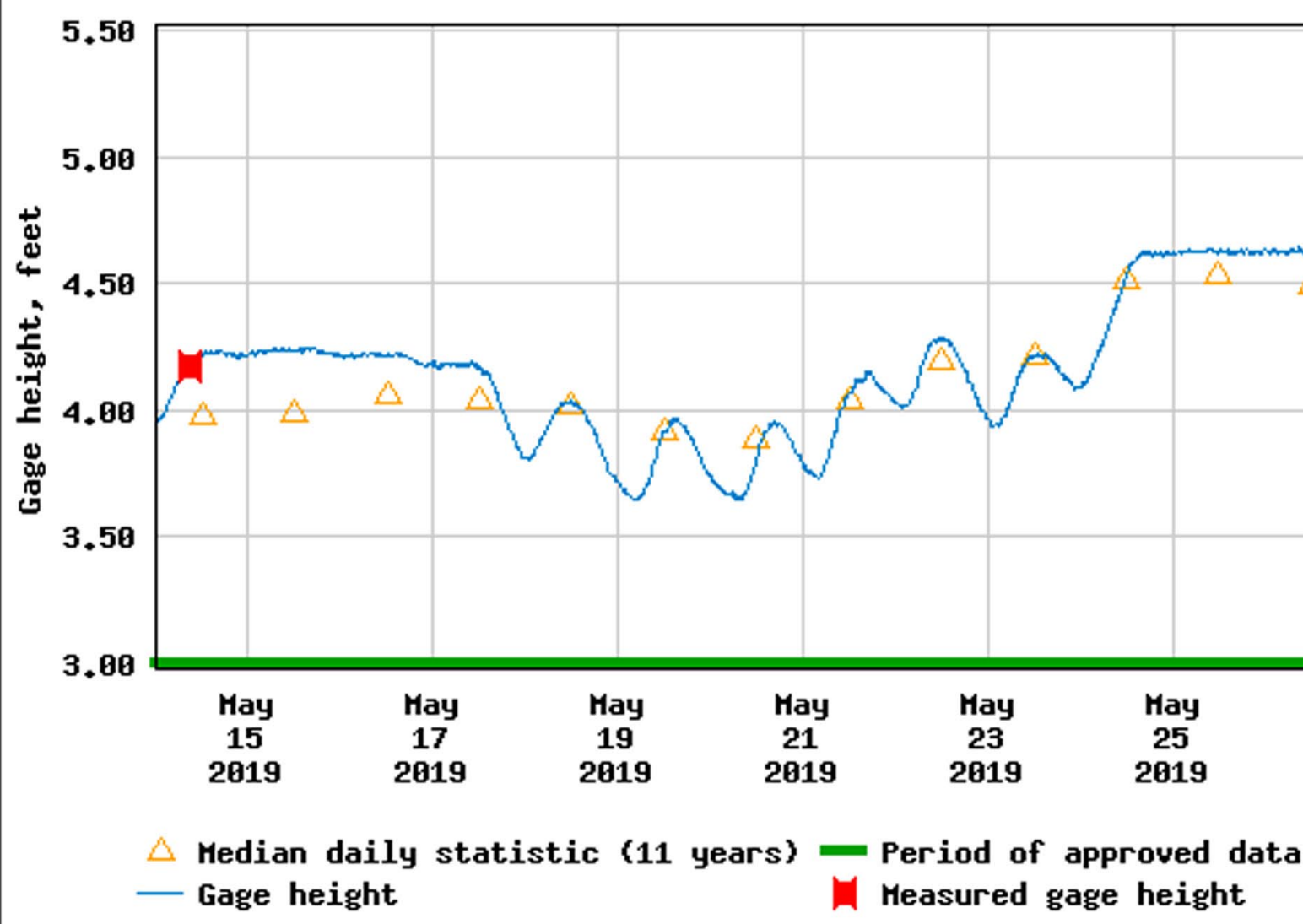

Figure 3. Observed Platte River gage height in feet at United States Geological Survey site no. 06770500 near Grand Island, Nebraska, from 15 to 27 May 2019, presented along with median gage height values (Figure Credit - USGS 2020).

$\left.\mathrm{ft}^{3} / \mathrm{s}\right)$ and $1.41 \mathrm{~m}(4.63 \mathrm{ft}$.) respectively and reached 164.0 $\mathrm{m}^{3} / \mathrm{s}\left(5,790 \mathrm{ft}^{3} / \mathrm{s}\right)$ and $1.62 \mathrm{~m}(5.3 \mathrm{ft}$.) by the evening of 27 May (Figure 2, 3; USGS 2020), by which time the sandbar used during this study had been completely submerged.

\section{Discussion}

The riverine sandbars the Snowy Plovers were found on were typical of nesting habitat described by Page et al. (2009). During the mating ritual, the female chooses the most suitable nest scrape made by the male (Page et al. 2009). As nest construction generally coincides with courtship, the female likely deemed the habitat suitable for nesting (Page et al. 2009). However, Boyd (1972) does mention the mating ritual and copulation may occur multiple times before the pair ultimately nests. Our data suggests that a single pair of Snowy Plovers stayed for at least
10 days in the CPRV near Mormon Island, Hall County, Nebraska, in May of 2019, but as the birds were unmarked it is impossible to know for certain. This was comparatively longer than the average stay length of three days or less reported by Silcock and Jorgensen (2018) for birds detected in Nebraska during the spring. This stay length suggests that given appropriate hydrological conditions, one to two pairs of Snowy Plovers may have attempted to nest at this site (Page et al. 2009, Silcock and Jorgensen 2018). Regional observations of Snowy Plover breeding chronology support this assertion (Silcock and Jorgensen 2018). Peyton and Wilson (2005) observed the first chicks fledged at lake McConaughy between the $15^{\text {th }}$ and $20^{\text {th }}$ of July in 2004 and 2005, indicating that nest initiation likely began in mid-May based on the typical rate of development for this species from egg to fledgling (50-55 days). 
Breeding has predominantly occurred in Nebraska when water levels were lower than average, which exposed larger than normal areas of sand for nesting (Silcock and Jorgensen 2018). Though water levels were relatively normal in the Platte River during our first observation of the Snowy Plovers, flows increased to well above median levels by 25 May (Figure 2,3). Well above average flows in June and July, peaking at $530 \mathrm{~m}^{3} / \mathrm{s}$ $\left(18,700 \mathrm{f}^{3} / \mathrm{s}\right)$ on 11 July 2019 , continued to limit available sandbar nesting habitat within the Platte River for Interior Least Terns and Piping Plovers, which are regular breeders regionally that have similar habitat requirements to Snowy Plovers (Kirsch et al. 1996, Page et al. 2009, Mohlman 2020). In recent years the majority of Interior Least Tern and Piping Plover nesting in the CPRV has occurred at off-channel habitats (e.g., sandpits) managed by conservation organizations specifically as breeding sites (Baasch et al. 2017, Mohlman 2020). Notably, unpublished data collected by the Headwater's Corporation (Kearney, NE, USA) indicates that a pair of Snowy Plovers brooded a 3-egg nest for nearly a month (6 June to 3 July) in 2019 about $45 \mathrm{~km}$ west of our study site and $2 \mathrm{~km}$ north of the main channel of the Platte River at a sandpit site near Newark, Nebraska, before the nesting attempt ultimately failed (K. Mohlman personal communication). The frequency, timing, and duration of high flows, as well as the ability of these flows to create suitable riverine sandbar breeding habitat, has been altered by extensive damming and diversion of the Platte River (Alexander et al. 2018, Caven et al. 2019). Though high variation in spring flows is part of the natural hydroregime of the Platte River, peak flows have not only been reduced but often delayed compared to the historic hydrograph (NRC 2005). Moreover, a large amount of sediment has been trapped behind dams, resulting in a reduction in the river's capacity to build sandbar heights above regular flood stage (Eschner et al. 1983, Alexander et al. 2020). The current and historic value of the Platte River for providing regular breeding habitat for significant metapopulations of ground nesting waterbirds has been a topic of recent and vigorous debate as a result of these relatively stochastic late spring and early summer flood pulse events as well as current sediment dynamics (Farnsworth et al. 2017, Alexander et al. 2018).

\section{Conclusions}

Snowy Plovers occasionally reproduce north of their core breeding range, but these sites are scattered across a large geographical region in the Central and Northern Great Plains (Gorman and Haig 2002, Page et al. 2009, Thomas et al. 2012). Breeding activity at these sites tends to be comparatively small-scale, involving a low number of breeding pairs, but it can also be relatively regular across years, such as at Lake McConaughy, Nebraska (Gorman and Haig 2002, Peyton and Wilson 2005, Thomas et al. 2012, Silcock and Jorgensen 2018). Scant information exists regarding Snowy Plover nesting ecology outside of their core breeding range, and there is very little explanation of spatially disjunct northern breeding occurrences in the literature (Gorman and Haig 2002, Thomas et al. 2012). It is likely that Snowy Plovers will continue to occur with low frequency in the CPRV, but occurrence may become more regular if habitat conditions become more consistently appropriate (Thompson and Ely 1989, Silcock and Jorgensen 2018). These observations improve our knowledge of the riverine habitats used by Snowy Plovers regionally and provide publically accessible documentation of a breeding season occurrence of notable length as well as mating behavior in the eastern portion of the CPRV. Future research should aim to more systematically document Snowy Plover occurrence in the CPRV and collect behavioral and ecological data from disparate and isolated breeding locations north of the species' core breeding range.

\section{Acknowledgements}

Research was funded by the Crane Trust and Johanna DeStefano via the Lila O. Wilson Biological Monitoring Internship. We want to thank Aurora Fowler for helping with field work, two anonymous reviewers for providing helpful comments regarding this short communication, Kari Mohlman for providing unpublished data from the Headwater's Corporation, Dr. Bruce A. Chase for his attentive shepherding of this manuscript, and Dr. Paul Royster for his excellent work formatting the final version. We appreciate the dedication of the Nebraska Academy of Sciences, Johanna DeStefano, and the Crane Trust to student-led natural history research.

\section{Literature Cited}

Alexander JS, Jorgensen JG, and Brown MB. (2018) Letter to the Editor: Reproductive ecology of interior least tern and piping plover in relation to Platte River hydrology and sandbar dynamics. Ecology and Evolution 8(11):5674-5679.

Alexander JS, McElroy B, Huzurbazar S, Elliott C, and Murr ML. (2020) Deposition potential and flow-response dynamics of emergent sandbars in a braided river. Water Resources Research 56(1):e2018WR024107.

Altmann J. (1974) Observational study of behavior: sampling methods. Behaviour 49:227-267.

Baasch, DM. (2010) 2008-2009 interior least tern and piping plover monitoring and research report for the central Platte River, Nebraska. Platte River Recovery Implementation Program, Kearney, Nebraska, USA, 49 pp.

Baasch DM, Farrell PD, Farnsworth JM, and Smith CB. (2017) Nest-site selection by Interior Least Terns and Piping 
Plovers at managed, off-channel sites along the Central Platte River in Nebraska. Journal of Field Ornithology 88(3):236-249.

Baasch DM, Farrell PD, Caven AJ, King KC, Farnsworth JM, and Smith CB. (2019) Sandhill Crane use of riverine roost sites along the central Platte River in Nebraska, USA. Monographs of the Western North American Naturalist 11(1):1-13.

Boyd BL. (1972) Breeding Biology of the Snowy Plover at Cheyenne bottoms waterfowl management area Barton County Kansas. Thesis, Emporia State University, Emporia, Kansas, USA, 96 pp.

Caven AJ, Buckley EMB, Wiese JD, Taddicken B, Krohn B, Smith TJ, and Pierson A. (2019) Appeal for a Comprehensive Assessment of the Potential Ecological Impacts of the Proposed Platte-Republican Diversion Project. Great Plains Research 29(2):123-135.

Eschner TR, Hadley RF, and Crowley KD. (1983) Hydrologic and morphologic changes in channels of the Platte River basin in Colorado, Wyoming, and Nebraska: A historical perspective. U.S.Geological Survey Professional Paper 1277-A, 39 pp.

Farnsworth JM, Baasch DM, Smith CB, and Werbylo KL. (2017) Reproductive ecology of interior least tern and piping plover in relation to Platte River hydrology and sandbar dynamics. Ecology and Evolution 7(10):3579-3589.

Google. (2018) Google Earth Pro (Version 7.3). Google, Mountain View, California, USA.

Gorman LR, and Haig SM. (2002) Distribution and abundance of Snowy Plovers in eastern North America, the Caribbean, and the Bahamas. Journal of Field Ornithology 73(1):38-52.

Johnsgard PA, and Brown MB. (2013) Birds of the Central Platte River Valley and Adjacent Counties. Zea E-Books, University of Nebraska-Lincoln Libraries, Lincoln, Nebraska, USA, 183 pp.

Johnsgard PA. (2018) The Birds of Nebraska. Zea E-Books, University of Nebraska-Lincoln Libraries, Lincoln, Nebraska, USA, 310 pp.
Kirsch EM. (1996) Habitat Selection and Productivity of Least Terns on the Lower Platte River, Nebraska. Wildlife Monographs 132:3-48.

Mohlman, K.L. (2020) 2019 interior least tern and piping plover monitoring and research report for the central Platte River, Nebraska. Executive Director's Office, Platte River Recovery Implementation Program, Kearney, Nebraska, USA, 48 pp.

National Research Council (NRC). (2005) Endangered and Threatened Species of the Platte River. National Academy Press, Washington, DC, USA, 299 pp.

Page GW, Stenzel LE, Warriner JS, Warriner JC, and Paton PW. (2009) Snowy Plover (Charadrius nivosus), version 2.0. In A.F. Poole and F.B. Gill, editors, The Birds of North America. Cornell Lab of Ornithology, Ithaca, NY, USA. https://doi.org/10.2173/bna.154.

Peyton MM, and Wilson GT. 2005. Snowy Plover nesting at Lake McConaughy in 2004 and 2005. Nebraska Bird Review 73:154-156.

Silcock WR, and Jorgensen JG. (2018) Snowy Plover (Charadrius nivosus), Version 1.0. In Birds of Nebraska. www. BirdsofNebraska.org

Thomas SM, Lyons JE, Andres BA, T-Smith EE, Palacios E, Cavitt JF, Mellink E, Melvin S, and Zimmerman T. 2012. Population size of snowy plovers breeding in North America. Waterbirds 35(1):1-14.

Thompson MC, and Ely C. (1989) Birds in Kansas. Museum of Natural History, University of Kansas, University Press of Kansas, Lawrence, Kansas, USA, 428 pp.

USGS (United States Geological Survey). (2020) USGS 06770500 Platte River near Grand Island, Nebraska (12 May 2019-27 May 2019). https:// waterdata.usgs.gov/nwis/ uv?site_no $=06770500$ 